\title{
The Language of Ecology within the Frame of Public Relations Discourse
}

\author{
(D)Alla Minyar-Beloroucheva ${ }^{1} \mathrm{PhD}$, Dr. habil.; (D) Polina Sergienko ${ }^{2}, \mathrm{PhD}$ \\ Lomonosov Moscow State University, Russia \\ ostvera@mail.ru' ${ }^{1}$; poserg@bk.ru²
}

\begin{abstract}
The article emphasizes the importance of the language of ecology in teaching English as a second language (L2) to public relations (PR) undergraduates. The research is aimed at making L2 PR undergraduates be aware of the necessity to protect the environment by means of reading specialized literature with a special focus on the language specifying issues of ecological ethics. Linguodidactics sees the educational ecosystem as one of its major trends of future development, as the undergraduates are not only to master single as such, but take them as a system pertaining to a human existence in the benevolent and harmonious world. Environmental conservation deals with sustainability, a subject to be taught through special vocabulary and professionally oriented texts. The methods employed in the present research include analysis and synthesis enabling the process of categorization and systematization. Theoretical achievements of linguodidactics in L2 professional education provide for the necessity to develop emotional competences, emotional intelligence, empathy, sympathy and sensitivity to the surrounding world. The research has shown that specially selected professionally oriented language units help the formation of a certain vision of the ecological situation in the modern world through the professionally oriented PR discourse. Ecological ethics for future PR experts becomes intrinsic for the development of their professional competences. Through the professional PR language, it is possible to establish an ecological aesthetic system aimed at promoting sustainable development regarding the environmental protection.
\end{abstract}

Keywords: lexical competence, language of ecology, ecology ethics, public relations discourse, PR undergraduates.

\section{Introduction}

We are living in the ever-changing environment of the fluctuating world, caused by the globalization process, which is the result of the technological advances of the developed world. Recently, globalization has shown a fairly steady and rapid progress, and has become an international driving force that due to progressive achievement has increased speed and scale to such an extent that countries all over the five continents have become engaged in this process and have been affected by it. Globalization is defined as a process based on international strategies, aimed at expanding business operations at the global level, and accelerated by the development of global communications as a result of scientific advancement, social, economic and political developments that cause environmental contamination. This can result in global environmental consequences affecting future generations. The process of global contamination occurs at a constant rate, independent of any environmental conditions. Moreover, scientists note that it has an intrinsically supranational character. The study of regional environment demonstrates the active engagement of people to conserve the environment. However, the world community considers that it is not only the duty of every state in the political sense (MinyarBeloroucheva et al., 2018), but every person on the planet to do so.

Globalization has influenced education, which in its turn is influencing the process of globalization per se. This fact is reflected in the worldwide educational reform called "deep learning". It implies a turn from traditional learning to a new comprehensive strategy incorporating practical tools and processes, as is postulated to lead to best ideas coming from practice, to engage undergraduates and educators into preparing the former for active, engaged participation in their future professional activity. In this case, the teachers are transformed into activators whose task is to develop global competence using real-life problem solving cases. Accordingly, the development of new competences is needed for the implementation of the "deep learning" idea into life. That is why the traditional competences are being substituted by new ones (Fullen, Quinn, McEachen, 2017). Scientists infer that to live in the global world it is better to concentrate on the development of global citizenship (Moreno et al., 2012) competences.

Developing global citizenship competences, which implies the involvement of PR undergraduates in active participation in projects that tackle numerous global issues such as social, political, economic of which the 
environmental ones are of primary importance, is unthinkable without developing emotional competence. The goals of education have become deeper. At present one of the priorities of L2 teaching to PR undergraduates is to equip them with the ability to feel the necessity to protect the environment and communicate this idea throughout the world to their counterparts in other places of the planet. For this purpose, it is most effective to use authentic materials in class to develop global citizenship and emotional competence among L2 undergraduates. It is impossible not to agree that authentic materials "bridge the gap between the classroom and the outside world and they bring reality to the classroom. Authentic materials are those which were not created or edited for language learners" (Reid, 2014). Authentic materials are the ones that are used in the real world of the professional PR sphere. They comprise documents, articles, books or press releases, that arouse among L2 PR undergraduates not only emotions of different kinds but the feeling of duty pertaining to the citizens of the world (The Clinton Global..., 2015 ) to preserve the global environment for the present and succeeding generations. Authentic materials are constructed of sentences made up of words and phrases that reflect the state of the art in every field of human activity on the global level that brings about pollution and contamination of the environment. In L2 teaching professionally oriented vocabulary mirrors the environment which is the habitat of the people. The properly chosen professionally oriented vocabulary develops emotional competences, in this case, aimed at the strive of contribution to sustainable development. Basic human values are revealed in the professional PR language corresponding to the main task of humanity to safeguard the future. The purpose of the study is to specify the necessity to protect the environment in the context of public relations discourse by developing PR undergraduates' lexical competence in teaching them the language of ecology.

\section{Methodology}

Methods and methodology play an important role in traditional research in general and in the research of PR discourse in particular. They are based on the international standards which are focused on the hermeneutic analysis of the text aimed at the development of L2 PR undergraduates' emotional competence. To implement the idea into practice, it was necessary to analyse PR texts of the international companies to use their press releases for didactic purposes. To achieve the goal, it is necessary to survey the material, to carry out a continuous sampling, to investigate the most effective language persuasive means as well as test the teaching methods and evaluate the results. The elaboration of new research methods and approaches aimed at revealing the content of PR discourse as well as studying the language ecology for the end of environmental protection and preservation through $\mathrm{L} 2$ teaching process is given a special prominence in this research. The current research demanded the semiotic approach to L2 professional PR language and PR discourse, methods of cognitive modelling of PR discourse, methods of philological analysis of PR discourse and didactic materials as well as category analysis. The methods of etymological and semiotic analysis taken for the study of professionally oriented discourse were also applied.

\section{Results and Discussion}

At present people have come to realize that everyone is obliged to preserve nature and the environment as well as take care of natural resources. Unlike the language of ecology that has not been the focus of linguistic attention, the problems of environmental protection and human exploitation of the environment have been prominent for decades. Environment specialists try to calculate the less damaging effect of the production industry. Environmental characteristics are based on the assessment of environmental data that on par with fluctuation in climate change has affected them. Thus, the climate warming of 1,5 degrees Celsius is considered a goal to minimize the harmful effect of human interference, as suggested by the UN's Environmental Programme - UNEP (UN's Environmental Programme..., 2020). Environmental conditions diversify different areas. Until the end of the previous century, little attention was paid to ecological contamination. It is substantiated by that fact that the first environmental conference was summoned only in 1972 in Stockholm - United Nations Conference on the Human Environment (UNCHE) (Heywood, 2011, 387). From that time on, the grounds were laid for UN initiatives and programmes to advance environmental protection actions globally. A lot of research was initiated at that time; however the issues were not given proper attention in the coming decades until recently. To prevent the acceleration decay of the modern environmental conditions, contemporary PR releases assure that their companies are doing their best to save the natural world by producing green products in line with the recommendations provided by UNCHE. Companies, such as Nestle, Procter and Gamble and even oil-producing Shell and BP strive to 
make products of inorganic materials to protect the environment. Special attention is paid to the most effective means of production and the use of electricity to facilitate the manufacturing processes.

Environmental ethics is becoming an advanced field of study for a good reason. It considers human beings as part of the biosphere, also known as the ecosphere, that consists of a number of ecosystems that is the natural field of life on the planet. Human beings interrelate with other species in the ecological system or ecosystem where despite their self-assurance to be dominant in the natural world, the environment governs their lives. Environment determines climate and vegetation, which in their turn influence animal life. All these things put together for centuries moulded the mode of human life. Although the environments did not enjoy the deserved attention in the previous centuries, at present the environment is not taken as something inalterable, constant or homogeneous through space and time anymore. This determines the greatest task of humanity to protect the environment. People do fret over climate change, de-forestation and the excessive emission of carbon dioxide into the atmosphere. The environment is regarded as something variable, constantly changing and being permanently in the state of flux. Nevertheless, it requires answers to a great number of broad questions of climate, de-forestation, the excessive emission of carbon dioxide. Environmentalists write declarations and articles on the necessity to stop the manufacturing enterprises that pollute and contaminate the environment. Words have the specific power of persuasion if they are uttered or written by the representatives of respected and powerful companies.

A recent trend of environment conservation deals with sustainability. It is one of the important steps to lessen the industrial and social impact on the globe. Environmental sustainability is defined as "a state in which the demands placed on the environment can be met without reducing its capacity to allow all people to live well, now and in the future" (GMET..., 2020). There are numerous indications of changes that occur in the field of natural resources. Environmental sustainability is necessary to decrease the usage of non-recurrent natural deposits and the results of human activities as well the effect on the biosphere of the planet. The task of environmental sustainability is thus to reduce the exhaustion of non-renewable resources. Sustainability can be comparable on the two sides of the coin, as we both benefit from sustainability and are accountable for its maintenance. Humans are responsible for the health, prosperity and well-being of the planet. There are various initiatives at maintaining the sustainable development for the sake of future generations. One of them is the educational part which includes raising awareness of popular measures and necessary actions to be taken to protect the environment. Environmental sustainability is a multifaceted concept that integrates environmental sustainability, economic sustainability, and social sustainability. They comprise the Three Pillars of Sustainability (UN General Assembly..., 2005) which serve the basis for harmonious existence and environmental conservation.

The aforementioned issues become especially relevant for L2 teaching to PR undergraduates, who will be professionally responsible for informing and educating the public in terms of environmental protection. It is necessary to state that although there is no unique definition of PR and the attitude of specialists is ambiguous, L2 PR undergraduates should not be misled about it. Thus, some scholars think of PR as a benevolent practice, essential for the society helping people to be conversant in this complicated world. One of the most successful definitions suggested by Dr. R. Harlow in 1976 summarizes various prior attempts to define the subject matter: "Public relations is a distinctive management function, which helps establish and maintain mutual lines of communication, understanding, acceptance and cooperation between an organization and its publics; it involves the management of problems or issues; helps management to keep informed on and responsive to public opinion; defines and emphasized the responsibility of management to serve the public interest; helps management keep abreast of and effectively utilize change, serving as an early warning system to help anticipate trends; and uses research and sound ethical communication as its principal tools" (Harlow, 1976: 36). Others are cautious and express their concern that well planned communication could mislead the people. Prominent linguist Professor Noam Chomsky puts people on their guard regarding PR campaigns. In particular, he writes, criticizing the PR practice that it has been used 'to further the ends of a few, regardless of the needs of many' (Wolstenholme, 2013: 3). This debate is a concern of separate investigations within the domain of ethical issues. However, major PR companies have grown conscious about the existing problem, it is the task for their management to adapt to the new situation. PR specialists are at the front line of popularization of the companies' actions and communication with the public concerned. The process of L2 teaching should be included into the system of general education as part of social sustainability, reinforcing 
the three pillars of sustainability. Learning L2 professionally oriented language is of primary importance for PR undergraduates. To be proficient and successful in one's career, future specialists should be able to communicate in L2 language on professional topics, to express their ideas on particular issues. One of the most important tasks of L2 PR undergraduates is to do their best to protect the environment. In this connection, special attention should be payed to the PR texts dealing with environment protection. Press releases express the policy of the companies on the above-mentioned issue. Moreover, the texts should be persuasive despite their specific construction. Examples of PR releases can support this idea.

Thus, one of the authentic texts taken for the research is an excerpt from a real-life PR text of the world's largest food and beverage company Nestlé, found in the company's sustainability report:

- Nestlé will continue to engage with all its suppliers to fulfill its no deforestation commitment more quickly. In particular, the company also recognizes the need for a collaborative approach to improve smallholder's capacity in eliminating deforestation. Nestle is working to find solutions that ensure sustainable supply chains while respecting people's rights to improve their livelihoods. (The Nestlé Policy..., 2013).

This corporate PR text highlights the necessity to preserve forests and states the company's commitment to this initiative. PR undergraduates learn about the urgency of environmental issues on the examples of authentic professional PR texts.

Another example cited here is borrowed from "Green and growing" online magazine promoting the issue of sustainable development:

- Since the Industrial Revolution, society has progressed immensely. However, the damages on the environment are measurable and scientists are concerned about the future of the planet. On the positive side, the development of biofuels and nuclear energy helped to reduce the burning of fossil fuels. The automotive industry, in particular, is trying to adopt a new scheme to build bio means of transportation such as the Hybrid. Elon Musk's Tesla cars prompted Volvo to plan to adopt the same technology in 2019 (What Is Environmental..., 2020).

This PR text specifies the importance of sustainable development. The Environmental contamination are much due to the industrial revolution and the progress thereafter. As is known from history, people first were not aware of the level of pollution their descendants will come up with. By studying the authentic text PR undergraduates can get the history of environmental damage inflicted by the human achievements throughout the time.

The next text taken as an illustration of the importance of employing authentic material for the didactic purpose in teaching PR undergraduates is an abstract from a PR press release of the global energy company BP plc.:

- We are delighted to be embarking on BP on the next phase of Aberdeen's drive to support local, national and international climate change targets. Jenny Laing Co-leader of Aberdeen City Council Councillor. "Our credentials are second to none for the deployment of ground-breaking technology in addressing climate change - the European Offshore Wind Deployment Centre, Hydrogen Aberdeen and the first bus fleet and refuelling infrastructure in the UK. (BP and Aberdeen..., 2020).

As seen from the example, at the present stage when the world has verbalized its major concerns about the high level of air, soil and water pollution, all major companies have started to verbalize their concerns regarding their professional activities. Future PR experts have a chance to learn from the authentic material to get a clear knowledge of the current developments and their actions as professionals in locum suum.

PR undergraduates should have no difficulties in choosing words and expressions to construct sentences and texts. To achieve this the vocabulary of L2 PR undergraduates should be rich, boosting their lexical enrichment. It means that despite the development of new competences (Fullen, Quinn, McEachen, 2017), the development of traditional ones should not be neglected. To reconcile traditional and new competences is the task of linguodidactics (Minyar-Beloroucheva et al., 2020). Linguodidactics is a kind of didactics that studies the interconnected process of a person's knowledge of the surrounding world, supervised by their educators. Distinctive features of linguodidactics are the recognition of its subject of language and its special consideration as a learning tool. The main goal of linguodidactics deals with 
the organization of a systematically implemented educational process, which consists in transferring knowledge, skills and abilities accumulated by previous generations in the field of a particular language to the undergraduates. To achieve this goal, linguodidactics solves the following tasks: determining the content of language education; development of the most effective ways and methods of teaching languages; selection of relevant and useful language knowledge, skills; identification of patterns of language learning. The objects of linguodidactics are considered the language as the subject of instruction, the process of learning and the factors that influence this process: the concept and paradigm of the current language education, its content, the organization of the educational process, technologies and methods for mastering knowledge (Vorontsova, Vishnyakova, 2018).

One of the traditional competences deals with the development of lexical competence, which is necessary to enrich the professionally oriented vocabulary. Under vocabulary is implied a set of words and phrases that form a system. In L2 professionally oriented teaching vocabulary is defined as lexical units that L2 PR undergraduates can acquire in the process of learning to be able to construct sentences to express their ideas. The increased attention to the study of vocabulary can be explained by a number of reasons: the content of the utterance depends on the degree of proficiency in vocabulary, the vocabulary to be learned is not uniform in its psychological and psycholinguistic characteristics, the learned lexical minimum should be considered as the basic (reference) vocabulary. It should be noted that the development of lexical skills is essential for such types of speech activities as listening, reading and speaking. The complex process of mastering an L2 professionally oriented vocabulary can be divided into several stages such as: introduction of new lexical units, semantic analysis, i.e., when the meaning of the new word is revealed, testing the understanding of the new lexical units, learning and memorizing the new professionally oriented vocabulary, training of the use and perception of new vocabulary. It is recommended for L2 PR undergraduates to learn new words independently where the teacher plays the role of an assistant and organizer and is called an activator (Fullen, Quinn, McEachen, 2017).

L2 PR undergraduates' development of lexical competence depends upon the method of L2 teachers/activators used in their professional activities. The modern communicative method of L2 teaching requires the development of $\mathrm{L} 2$ lexical competence in real communication situations that meet the needs of professionally oriented L2 PR undergraduates. Previously reading aloud, translating words into the native language and memorizing them was a traditional method of L2 teaching. At present, such a method is considered obsolete as it counteracts the method of L2 practical mastery aimed at achieving the necessary level of communicative competence. Moreover, such a method does not develop L2 undergraduates' thinking, nor contributes to the development of L2 intuition. That is why new competences have been recently developed and are being implemented in the educational process. They are known as 6Cs (six competences) as they include the following six competences: character, collaboration, communication, creativity, critical thinking and citizenship (Fullen, Quinn, McEachen, 2017).

To acquire a new vocabulary L2 teachers/activators should scaffold (Ikawati, 2020) L2 PR undergraduates by using such methods as explaining the meaning of the new vocabulary by means of the non-verbal demonstration, or explanation through context, using synonyms, antonyms and paraphrasing. L2 teacher/activators should encourage L2 PR undergraduates to do language guesswork when teaching vocabulary. There are various exercises for training vocabulary to consolidate the knowledge within the professional field of study. The basic principles for vocabulary training are: systematism, situationism and undergraduates' independent work. Exercises should reproduce a real situation of communication, they should be varied, interesting and develop the language abilities of the undergraduates.

For L2 PR undergraduates dealing with environmental protection and ecology, it is necessary to know that the development of humanity should be ecologically sustainable. L2 PR undergraduates should be aware of the possible ways of reconciling environment and ecology to preserve the planet from entropy. The more L2 PR undergraduates know about these phenomena the more they can do in the future. Their knowledge should start with the understanding of the term 'ecology'. This term 'ecology' owes its emergence to prominent German zoologist Ernst Haeckel in the middle of the $19^{\text {th }}$ century. The term is derived from the Greek 'oikos' meaning household or environment, where the correlation of living and inanimate nature is of primary importance for their harmonious existence. Thus for Ancient Greeks, ecology and environment were an integral whole. At present, they are the terms of different academic disciplines. Despite the existing separation, scholars and Green Peace activists want to return them to 
the primordial sense. For the sake of preservation of human beings, flora and fauna, inanimate nature of our planet measures are taken to draw attention to the issues of ecosystems, human intervention and harmful effects of exploiting natural resources. Thus, the focus is put on the existence of human beings in the modern ecosystem. As a political ideology, ecology is gaining momentum (Heywood, 2011, 384). Ecology is given the priority for the issue of preserving the environment for the future generations, language being one of its most persuasive tools.

Most present-day PR campaigns and programmes of Corporate Social Responsibility of giant multinational companies aim at promoting the idea of sustainable development. This indicates that their predominant effort is to keep in line with the conservation policy of the environment conscious countries. Language policy is this regard fosters the achievement of the goal. Language ecology is defined as the study of the interactions between any given language and its environment. The true environment of a language is the society that uses it as one of its codes. (Haugen, 1972). A new language is needed (Bentley, 2020) which can be created on the basis of the work of PR undergraduates doing research on nature preservation. Scientists claim that the language of ecology can be equated with society. The foundation works prove that it is necessary to additionally identify the dominant ecological context, within which the development is unfolding. Other theorists devote special attention to different aspects of ecological ethics implication (Scheid, 2016; Jia, 2020).

When speaking about the education of PR undergraduates, it is important to bring closer the professional L2 discourse with the most relevant issues (Table 1).

Table 1

Examples of lexical phrases mirroring the problem of environmental pollution and its solution.

\begin{tabular}{|l|l|l|l|}
\hline \multicolumn{1}{|c|}{$\begin{array}{c}\text { Environmental } \\
\text { disasters }\end{array}$} & \multicolumn{1}{|c|}{$\begin{array}{c}\text { Environmental } \\
\text { protection projects }\end{array}$} & $\begin{array}{l}\text { Plans to avoid damage to } \\
\text { the environment }\end{array}$ & $\begin{array}{c}\text { Environmentally friendly } \\
\text { advanced technology }\end{array}$ \\
\hline $\begin{array}{l}\text { climate change; } \\
\text { greenhouse effect; } \\
\text { global warming }\end{array}$ & $\begin{array}{l}\text { to protect forest; to } \\
\text { replant trees; to } \\
\text { enhance biodiversity; } \\
\text { zero deforestation }\end{array}$ & $\begin{array}{l}\text { to limit greenhouse gas } \\
\text { emissions }\end{array}$ & $\begin{array}{l}\text { the use of energy from } \\
\text { renewable sources }\end{array}$ \\
\hline $\begin{array}{l}\text { deforestation accele- } \\
\text { ration; acid rains }\end{array}$ & $\begin{array}{l}\text { to decontaminate the } \\
\text { environment }\end{array}$ & $\begin{array}{l}\text { to achieve zero net } \\
\text { greenhouse gas emissions }\end{array}$ & the development of biofuels \\
\hline $\begin{array}{l}\text { the burning of fossil } \\
\text { fuels; carbon dioxide } \\
\text { emissions, Hydro- } \\
\text { Carbon engine } \\
\text { releases }\end{array}$ & $\begin{array}{l}\text { biomaterials to store } \\
\text { carbon dioxide }\end{array}$ & $\begin{array}{l}\text { to achieve zero net } \\
\text { greenhouse gas emissions; } \\
\text { promotion sustainable } \\
\text { development; bio/circular } \\
\text { economy }\end{array}$ & $\begin{array}{l}\text { hybrid transportation } \\
\text { hyeans of transportation; }\end{array}$ \\
\hline $\begin{array}{l}\text { chemical releases } \\
\text { into streams without } \\
\text { treatment }\end{array}$ & $\begin{array}{l}\text { moving to alternative } \\
\text { packaging materials }\end{array}$ & $\begin{array}{l}\text { to limit global temperature } \\
\text { rise to } 1.5^{\circ} \mathrm{C}\end{array}$ & $\begin{array}{l}\text { Ground breaking technology; } \\
\text { industry know-how }\end{array}$ \\
\hline $\begin{array}{l}\text { soil degradation } \\
\text { climate-friendly }\end{array}$ & $\begin{array}{l}\text { programs with farmers to } \\
\text { restore land }\end{array}$ & $\begin{array}{l}\text { more sustainable formulas for } \\
\text { climate change; } \\
\text { bioremediation }\end{array}$ \\
\hline
\end{tabular}

Together with instructing PR undergraduates on their professionally oriented foreign language, it is essential to in still the relevance of language ecology and ecological ethics. Through the professional PR language, it is possible to establish an ecological aesthetic system aimed at promoting sustainable development. As language determines the worldview, in it is necessary to stimulate L2 PR undergraduates to read the texts and thus learn the vocabulary dealing with environment protection. L2 PR undergraduates should be absolutely trustworthy of the information contained in PR press releases. The ecological vocabulary used there can be classified into several groups indicating the companies' concern for the environment.

To harmonize (Vishnyakova et al., 2020) and develop traditional and new competences L2 PR undergraduates should be prompted by their activators to work in teams 1) Here is a list of words dealing with the environment protection, which function in the set of texts. Add the related words connected with the present situation. Read out loud the words and phrases to be expanded on them by your team mates; to work out a project dealing with "Our journey to net zero"; 2) prepare a presentation on the subject "Global citizens 
on the reduction of greenhouse gas emissions"; 3 ) write a call "1.2 million cars off the road"; 4) organize a mini-conference on "The responsible sourcing of its raw materials"; 5) write a press release "Setting a bolder ambition to reach a net-zero future"; 6) make up a story concerning the environment protection using the terms from the text. Discuss it with fellow students; 7) make videos showing the pollution of the environment and how to improve the situation to demonstrate innovative leadership in reality.

These are only several strategies how to reconcile traditional and new competences. The subject matter should be properly chosen as the new words that are trained during class and independent types of work are kept in mind when setting certain guidelines for future L2 PR undergraduates' activities.

\section{Conclusions}

At present, the language of ecology reflects is the main trend in treating the ecosystem of our planet through instilling concern for ecological ethics. The language of ecology which is of great help serving these purposes, is not only noted for its purity, it is aimed at constructing the mental space of L2 PR undergraduates in which an ideal zero deforested and net-zero future world could be visioned. The educational system should prepare the future PR councillors to be actively involved in their future environmental protection and sustainable development. To achieve this, new competences, known as $6 \mathrm{Cs}$, such as character, collaboration, communication, creativity, critical thinking and citizenship have been developed. In a rapidly changing globalizing world, when environmental disasters become prominent, it is essential to address the issues of climate change, greenhouse effects; global warming, deforestation acceleration; acid rains, burning of fossil fuels; carbon dioxide emissions, Hydro-Carbon engine releases, chemical releases into streams without treatment, soil degradation and other environmental disasters caused by the human activity. Theoretical achievements of linguodidactics make it possible to introduce the language of ecology into the professionally oriented teaching of the second language to work out ecological ethics, necessary for nature preservation and safeguarding the future.

\section{Bibliography}

1. Bentley M. (2020). A new language for ecological public health. In Australian Public Health Conference Retrieved from:

https://www.researchgate.net/publication/344912880_A_new_language_for_ecological_public_health

2. BP and Aberdeen join forces in drive for net zero. (2020). Retrieved from https://www.bp.com/en_gb/united-kingdom/home/news/press-releases/bp-and-aberdeen-joinforces-in-drive-for-net-zero.html

3. Fullen M., Quinn J., McEachen J. (2017). Deep Learning: Engage the World Change the World. Thousand Oaks, CA: Corwin Press.

4. GMET General Multilingual Environmental Thesaurus. (2020). Retrieved from https://www.eionet.europa.eu/gemet/en/concept/15163

5. Harlow R. F. (1976). Building a Public Relations Definition. Public Relations Review, 2(4).

6. Haugen E. (1972). The Ecology of Language. Stanford, CA. Stanford University Press.

7. Heywood A. (2011). Global Politics. Palgrave McMillan. Retrieved from https://peda.net/jao/lyseo/isac/ias/global-politics/ahgp/the-whole-

book:file/download/e7ab471d24086998cb255025c53dc75c3c92ed9c/Andrew-Heywood-GlobalPolitics\%20\%28kopio\%29.pdf

8. Ikawati L. (2020). Scaffolding in Teaching Writing. AL-TARBIYAH Jurnal Pendidikan (The Educational Journal), 30(1), 48-58. doi: 10.24235/ath.v30i1.6487

9. Jia C. (2020). The Ecological Ethical Implications of Latour's Gaia Theory. Philosophy Study, 10(1), 29-35. doi: 10.17265/2159-5313/2020.01.004

10. Minyar-Beloroucheva A., Sergienko P., Vishnyakova E., Vishnyakova O. (2020). New Linguiodidactic Challenges in Teaching Professionally Oriented English As Referred To PR-Education. In European Proceedings of Social and Behavioural Sciences, 97, 539-547. doi: 10.15405/epsbs.2020.12.02.72

11. Minyar-Beloroucheva A., Sergienko P., Vishnyakova O., Vishnyakova E. (2018). Modern technologies in teaching professionally oriented foreign language to the students of politics. In L. Gómez Chova, A. López Martínez, I. Candel Torres (Eds.) The Proceedings $11^{\text {th }}$ 
International Conference of Education, Research and Innovation (ICERI2018). Seville, Spain: IATED Academy, 7967-7975. doi: 10.21125/iceri.2018.0043

12. Moreno D.R., Pérez D., Díez-Bedmar M.B., Garcia-Ramirez P. (2012). Developing global citizenship competence in English Studies: a proposal of activities. München: Lincom GmbH

13. Reid E. (2014). Authentic Materials in Developing Intercultural Communicative Competences. In Conference Proceedings International Conference on Language, Literature and Culture in Education (LLCE2014). Nitra, Slovakia: SlovakEdu, o.z. Nitra, 160-167. Retrieved from http://files.jolace.webnode.sk/200000148-

1e51e1f4bb/LLCE\%202014\%20Conference\%20Proceedings.pdf

14. Scheid D.P. (2016). The Cosmic Common Good as a Ground for Interreligious Ecological Ethics: Religious Grounds for Ecological Ethics. doi: 10.1093/acprof:oso/9780199359431.003.0001

15. The Clinton Global Citizen Awards. (2015). Clinton Global Initiative. Retrieved from https://web.archive.org/web/20150923204736/http://www.clintonglobalinitiative.org/ourmeeting s/2012/clinton_global_citizen_awards/

16. The Nestlé Policy on Environmental Sustainability. (2013). Retrieved from https://www.nestle.com/sites/default/files/asset-

library/documents/library/documents/environmental_sustainability/nest1\%C3\%A9\%20policy\%2 0on\%20environmental\%20sustainability.pdf

17. UN General Assembly. (2005). World Summit Outcome: resolution / adopted by the General Assembly, 24 October 2005, A/RES/60/1. Retrieved from https://www.refworld.org/docid/44168a910.html

18. UN's Environmental Programme. (2020). Retrieved from https://www.unenvironment.org

19. Vishnyakova O., Minyar-Beloroucheva A., Sergienko P., Vishnyakova E. (2020). Harmonizing different cognitive styles through reading. In T.V. Petkova, V.S. Chukov (Eds.), The Proceedings of the International e-Conference on Studies in Humanities and Social Sciences, 5. Belgrade: Center for Open Access in Science, 17-30. doi: 10.32591/coas.e-conf.05.02017v

20. Vorontsova M., Vishnyakova O. (2018). Basic principles of national and international standards convergence in teaching languages for non-linguistic students. In V. Dislere (Ed.), The Proceedings of the International Scientific Conference Rural Environment. Education. Personality (REEP), 11. Jelgava: Latvia University of Life Sciences and Technologies, 148-154. doi: 10.22616/REEP.2018.017

21. What Is Environmental Sustainability and Why Is It Important? (2020). Retrieved from https://www.greenandgrowing.org/environmental-sustainability/

22. Wolstenholme S. (Ed.). (2013). Introduction to Public Relation. Pearson Education Limited. 